\title{
Comparative Analysis of Metacognitive Skills and Self Assessment of Economics Students' Achievement in Edo South Senatorial District, Edo State, Nigeria
}

\author{
Aituriagbon Kingsley Ehis, PhD \\ Department of Educational Evaluation and Counselling Psychology, \\ Faculty of Education, University of Benin, Benin City, Nigeria \\ Oribhabor Chinelo Blessing, PhD \\ Department of Guidance and Counselling, Faculty of Arts \& Education, \\ University of Africa, Toru, Orua, Bayelsa State, Nigeria
}

\begin{abstract}
This paper focuses on comparing the analysis of Economics student's metacognitive skills and self-assessment. The design of the study is a descriptive research survey, and the study population comprises of all the Economics senior secondary II students in Edo South Senatorial District of Edo State, Nigeria. The sample size of this study consists of 390 Economics senior secondary school class II. The instrument used for this study is a questionnaire, which was validated by expert in Measurement and Evaluation as well as Educational Psychology. The Cronbach Alpha reliability was used to determine the consistency of the instrument which was at 0.84 . The data collected was analyzed using Pearson's product-moment correlation to determine the relationship between metacognitive skills, self-assessment, and Economics student's achievement. The two hypotheses were tested at 0.05 level of significance. Firstly, the data analysis showed that there is a relationship between metacognitive skills and Economics students' achievement. Secondly, it also shows that self-assessment is related to the achievement of Economics students. From the findings, it was recommended that Economics teachers should give Economics students more homework that will compel the students to search for information online (e-learning). Secondly, Economics teachers should consistently monitor, check when relevant, and reply the Economics students based on the assignment given to them. Finally, a significant relationship exists between students' metacognitive skills and determinant of academic performance.
\end{abstract}

Keywords: Economics students, metacognitive skills, self-assessment, student's achievements 


\section{Introduction}

Over the years, a lot of explanations have been provided concerning the poor achievement of the Economics students. Some of the factors that could have affected Economics achievement of students negatively includes: students interest in the subject that has been taught, misconception between concepts in economics and commerce, poor background in statistics and student's attitude towards the subject. However, this also includes teachers approach and methodology applied in teaching economics, and their inquisitiveness to present instructional materials to display what is been taught (Abu, 2007). Several kinds of literature have emphasized on two types of assessment, namely: summative and formative assessment. However, Josual (2019) and Emeke (2019) opined that there are three types of learning, namely: learning assessment (Summative), assessment for learning (formative), and assessment as learning (metacognitive skills and self-assessment). This study seeks to emphasize on the applications of metacognitive skills and selfassessment, and how it can enhance economics student's academic achievement.

Assessment is the key to learning. Without assessment, the performance of the students cannot be well ascertained. Hence, there is the need to understand the concept of assessment. Assessment can be regarded as the process or activity that is scheduled to gather information about learner's ability based on what he/she has learnt over time (Greaney, 2001). Josual (2019) viewed assessment as the collections of relevant data, whether qualitative or quantitative, which could be used for making decisions. This study will also consider aspects of assessment such as continuous assessment, classroom assessment, and performance assessment. There is always a misconception about classroom assessment; however, it is necessary to explain the difference between continuous assessment and classroom assessment. Continuous assessment could be regarded as a formative assessment. Continuous assessment is when the teacher consistently assessed the learner in order to determine the learner's performance and also to determine his/her performance as a teacher.

Airasian (1991) opined that continuous assessment is a method which the teacher can use to collect, analyze, and interpret information about learners. Kugamoorthy and Weerakoon (2018) continuous assessment is related with Activity-Based Assignment (ABA). It is a method of continuous assessment which allows learners to go home with what has been taught in school and respond to questions at home to help the teacher ascertain the performance of the learner. Igba, Samiullah and Aysha (2017), in their study, show that continuous assessment has positive effects on learner's achievement. Teachers who are well knowledgeable in evaluation and assessment techniques should be motivated and encouraged. Also, their 
expertise should be adequately used for the purpose of enhancing student's achievement. Continuous assessment is the act of seeking and interpreting concrete evidence for use by the students and their teachers to determine where the students are in terms of academic performance, where they need to be, and how best they could do better and get to the top as expected. The attribute of continuous assessment are: to enable the students to think, for the students to promote deeper learning and understanding, for the teacher to develop teaching strategy, and for students to develop learning skills (Hargreaves, 2005).

Performance assessment is not a new concept, but it is as old as assessment itself. It is an assessment that is used to judge learner's competencies in applying knowledge and cognitive skills to tackle substantive and meaningful task (Lane, 2010). Performance assessment is needed to assess the type of thinking and reasoning skills that are relevant to teachers rather than the usually multiple-choice items. Therefore, it is pertinent to know that performance assessment differs from continuous assessment and classroom assessment. Performance assessment is also known as constructed-response assessment. Features of C.R.A are: open and items, essays, problem-based, scenario, performance tasks, projects, research papers, oral presentations, etc. However, Lane (2010) insisted that the purpose of performance assessment is to assess complex cognitive skills and reasoning ability. As a result, there is the need to consider the concept of self-assessment and metacognitive skills. Self-assessment and metacognitive seems to be more advance than the previous assessment defined.

In Self-Assessment (S.A), the teacher should guide the learner on how to perform a task than the teacher performing the task. Self-assessment is a unique concept because the teachers play a passive role while the learners play an active role. Self-assessment entails making a decision about expected learner's performance and making judgment about the quality of the performance in relation to the standard. Self-assessments enable learners to develop their personal learning skills and to become aware of how they learn. Self-assessment is a valuable approach to determine student's learning strategy (Wride, 2017). Standards-based education is a criterion that can be used to determine learner's self-assessment. This is because learners are expected to monitor and assess the quality of their thinking and also to identify the strategy that has helped them improve on learning. McMillan and Hearn (2008) study on student's assessment concludes that when students get goals that aid and improve their understanding, it helps them to identify criterion, perform a self-assessment of their progress towards learning, reflect on their learning and generate strategies for more learning. This will result to improved performance with meaningful motivation. 
Ajai (2018) study indicated that visual representative peer tutoring and self-instructional learning, which could be regarded as self-assessment, is correlated with both metacognitive and cognitive domain. He further concluded that self-instructional strategies peer tutoring have a significant positive impact on student's achievement. Nalah (2014) in his study on selfassessment and student's academic performances in Nigeria colleges of education, using 412 responses with $51 \%$ male and $49 \%$ female, concluded that there is a difference over between self-concept. However, this could be self-assessment and academic performance of NCE1 students and NCE III students irrespective of age, gender, and socio-economic background. As a recommendation, students should learn to be courageous, independent, exercise creative thinking, confidence in judgment, and psychologically upright. This will enable them to overcome academic challenges. Olaoye and Olaoye (2018) study on self-esteem, locus of control, and achievement motivation asserted that self-esteem is more correlated with students' achievement motivation. In addition, the self-esteem of the female is more correlated with achievement than their locus of control.

Metacognitive skills is an aspect of assessment in learning, while John Flaveil 1979 is the proponent of metacognitive skills. Although others scholars have to define metacognitive skills in their approaches, some regarded metacognitive as thinking or about thinking (Flaveil 1979). Others consider metacognition as knowledge of cognition and regulation of cognition (OZ, 2014; Chamot, 2004). However, metacognitive skill is characterized as teachers as learner trainers, teacher as supervisor, and teacher as a coach. This is synonymous with self-assessment where teachers are passive and learners are mostly active. GOK (2010) opined that metacognitive knowledge is a declarative procedure and strategy; thus metacognitive components are intelligence, regulation, knowledge, and strategy. Owo and Ikwut (2015), in a study on the relationship between metacognitive, attitude and academic achievement of students, concluded that metacognition and attitude are good predictors of academic achievement. However, the student's achievement as a result of metacognition is based on his/her personal interest to learn effectively. Ibe (2009) also ascertained that metacognition is a strong prediction of student's academic performance. Thus, this will enhance student's problem-solving skills.

Metacognitive awareness inventory is a tool used to determine metacognitive skills, while metacognitive awareness inventory is a potential instrument needed by psychologist, teachers, and psychometricians to identify students requiring metacognitive skills (Young \& Fry, 2008). Gaylo (2019) study on metacognitive skills, concept mapping, thinking aloud, and journal writing opined that incorporating the above concept into teaching and learning will lead to a variety of metacognitive skills which will enable the students to 
learn and understand effectively. The behavioral and cognitive attribute of the students is very important. This can be achieved through adequate knowledge in metacognitive skills and also the application of metacognitive skills.

\section{Purpose of the Study}

The purpose of this study is to comparatively analyze metacognitive skills and self-assessment as related to Economics student's achievement, precisely to determine if:

1. Student's metacognitive skills relate to academic achievement.

2. Student's self-assessment as a correlation with academic achievement.

\section{Hypothesis}

i. There is no significant relationship between students' metacognitive skills and academic achievement in Economics.

ii. There is no significant relationship between student selfassessment and academic achievement in Economics.

\section{Methodology}

The descriptive survey research design was adopted in conducting the study. The population is made up of all the Economics Senior Secondary School II students in Edo South Senatorial District, Edo State, Nigeria. The strategic random sampling was used. First, three (3) local government areas were randomly selected from the seven (7) local government area. Thus, two (2) secondary schools each was selected from the three local government with sixty-five (65) Economics students from each of the schools. The participants in this study are three hundred and ninety (390) Senior Secondary School Class II Students. The instrument used in the study is the Economics Achievement Test using self-skills scale/inventory, metacognitive, and selfassessment scale which are 4-Likert rating scale. Content validity was used, and this was done by experts in educational psychology, measurement, and evaluation. The Cronbach Alpha reliability was used to determine the consistency of the instrument which was at 0.84 , indicating that the instrument is suitable and consistent for research purpose. The instrument was administered and analyzed using Pearson's product-moment correlation to test the hypotheses at 0.05 level of significance.

\section{Results}

Hypothesis One: There is no relationship between metacognitive skills and Economics students achievement. 
Table 1. Pearson Product Moment Correlation of Metacognitive Skills and Economics Students Achievement

\begin{tabular}{|l|c|c|c|}
\hline Variable & N & Pearson's r & Sig.(2-tailed) \\
\cline { 1 - 4 } Metacognitive skills & \multirow{2}{*}{390} & 0.374 & 0.00 \\
\hline Achievement & $\boldsymbol{\alpha}=0.05$ \\
\hline
\end{tabular}

The table above shows Pearson's correlation value of 0.374 and a $\mathrm{p}$-value of 0.00 , testing at an alpha level of 0.05 . However, the p-value of 0.000 is less than the alpha level of 0.05 . Therefore, the null hypothesis which states that there is no significant relationship between metacognitive skills and Economics student's achievement is rejected. Thus, there is a relationship between metacognitive skills and Economics student's achievement.

Hypothesis Two: There is no significant relationship between self-assessment and economics student's achievement.

Table 2. Pearson's Product Moment Correlation of self-Assessment

\begin{tabular}{|l|c|c|c|}
\hline Variable & N & Pearson's r & Sig. (2-tailed) \\
\cline { 1 - 4 } Self-assessment & \multirow{2}{*}{390} & 0.513 & 0.000 \\
\hline Achievement & & 0.000 \\
\hline
\end{tabular}

The table above shows Pearson's correlation value of 0.513 and a $\mathrm{p}$ value of 0.00 , testing at an alpha level of 0.05 . However, the p-value of 0.000 is less than the alpha level of 0.05 . Therefore, the null hypothesis which states that there is no significant relationship between self-assessment and Economics student's achievement is rejected. Thus, there is a significant relationship between self-assessment and economics student's achievement.

\section{Discussion of Findings}

Hypothesis one revealed that there is a significant relationship between metacognitive skills and Economics student's achievement. The result of this study is in agreement with the findings of Owo and Ikwu (2015), which state that metacognition and attitude are a good predictor of student's academic achievement. Ibe (2009) findings also agree with this study that metacognition is a strong predictor of student's academic achievement. The result of hypothesis one is also in line with Gaylo (2019) which conclude that behavioral attitude of students/learners are very crucial and this can be achieved through knowledge in metacognitive skills.

The result of hypothesis two showed that there is a significant relationship between self-assessment and Economics student's academic achievement. The result of this study is in line with the study of Olaoye and Olaoye (2018) and McMillan and Hearn (2008). In their study, they found that self-esteem (self-assessment) are more related to student's academic 
achievement. Also, the application of self-assessment creation tool will lead to student academic performance.

The result of both hypotheses is in line with Ajai (2018), who found that self-assessment and metacognitive skills are correlated with student's academic performance. This can be achieved with the aid of self-instructional strategy and peer tutoring.

\section{Conclusion}

Economics students are not learning in isolation. They are now well equipped with the appropriate approach of learning. Economics students are now more independent on their teachers because of their ability to think outside the box. Also, they were able to discover themselves with a little guidance from their class teacher and their ability to work in solving economics problems. Metacognitive skills, soft skills, and self-assessment are excellent pre-requisite of Economics student's academic achievement.

\section{Recommendations}

Based on the findings, the following recommendations are made:

1. Economics teachers should give the Economics students more homework (assignment) that will compel the students to search for information online (internet), and that will cause them to make adequate use of their calculators and mathematics set.

2. The school's Information Communication Technology (ICT) laboratory should be functional so as to help the student have access to information, hence leading to self-assessment.

3. Students should be given self-assessment scale and metacognitive inventory. This will enable the teacher to ascertain the student's interest towards self-assessment and metacognition.

4. The Economics teachers should consistently monitor, check when relevant, and reply/correct the economics students based on the assignment given to the students.

\section{References:}

1. Abu, E.O. (2002). Two Problem Based Learning Strategies, Qualitative Abilities and Gender as Determinant of Student's Academic Achievement in economics. (Ph.D. Thesis) University of Ibadan, Ibadan.

2. Ajai, J.T. (2018) Evaluation student's achievement in mathematics through systematic and implicit instruction, self-instruction, peer tutoring and visual representation. International Journal of Contemporary Research and Review, 9(8).

3. Airasian, P.W. (2001).Classroom Assessment. New York Mc-Grawhill 
4. Chamot, A.U. (2004). Issues in Language learning strategy research and teaching. Electronic Journal of Foreign Language Teaching, 1 (1): 14-26.

5. Emeke, F.A. (2019). Assessment for Institutional Quality and Improvement Paper Presented at the $21^{\text {st }}$ Annual Conference of Association of Educational Evaluation and Researchers of Nigeria at Obafemi Awolowo University.

6. Flavell, J.H. (1979). Metacognition and cognitive monitoring: A new area of cognitive developmental inquiring. American psychologist, 34(10).

7. Flavel, J.H. (2004). Theory of mind development retrospect and prospect. Merril Palmerovarterly 50, 277-290.

8. Gaylo, D. (2019). Metacognitive Strategies; Their effects on students' academic achievement and engagement in Mathematics.

9. Gok, T. (2010). The General Assessment of Problem Solving and Metacognition in Physics Education. European Journal of Physics Chemistry Education, 2(2):110-122.

10. Greaney, V. (2001). Using assessment to improve the quality of education. Paris: UNESCO International Institute for Education Planning.

11. Hangreaves, E. (2005). Assessment for Learning? Thinking outside the (black) box. Cambridge Journal of Education 35 (2): 213-224.

12. Ibe. N.G. (2009). Metacognitive Strategy on Classroom Participation and Student's Achievement in Senior Secondary School Science Classroom. Science Education International, 20 (1\&2):25-31.

13. Igbai, M; Samilulah, L. \& Anjum, A. (2017). Effect of Continuous Assessment Techniques on Student's Performance at Elementary Level. Bulletin of Education and Research, 39(1): 91-110.

14. Joshua, M.T. (2019). Assessment Quality in the $21^{\text {st }}$ Century: Implications for institutional improvement. A paper presented at $21^{\text {st }}$ Annual Conference of ASSEREN at Obafemi Awolowo University, Ile-Ife on July 22-26.

15. Kugamoorthy, S. \& Weerakoon, S. (2018). Continuous Assessment Methods: Critical review for quality improvement of the Postgraduate Diploma in Education Programme of the Open University Sri Lanka. International Research Journal of Human and Social Sciences, 5(10).

16. Lane, S. (2010). Performance assessment: The state of the art (SCOPE Student Performance Assessment Series). Standard, CA: Stanford University, Stanford Centre for Opportunity Policy in Education.

17. McMillan, J.H \& Hearn J.M. (2008). Student self-assessment motivation and higher achievement. Educational horizon. 
18. Nalah A.B. (2014). Self-concept and student's academic performance in the college of education. Akwanga, Nasarrawa State, Nigeria. World Journal of Young Research, 2(3):1-7.

19. Olaoye, O.T. \& Olaoye D.D. (2018). Assessment of Self-esteem, locus of control and achievement motivation of female students in Kwara State College of Education, Nigeria. Educational Process. International Journal, 7(3): 207-221.

20. Owo, W.J. \& Ikwut, E.R. (2015). Relationship between metacognition, attitude and academic achievement of secondary school chemistry students in Port Harcourt, Rivers state. Journal of Research and Method in Education, 5(6): 06-12.

21. Oz, H. (2014). The relationship between metacognitive awareness and academic achievement among English as a foreign language teachers. In J. Huang \& A.C Fernades (eds), Non-native language teaching and learning. Putting the puzzle together (139-167). New York, NY: Untested Ideas Research Centre.

22. Wride, M. (2017). Guide to self-assessment. Academic practice and elearning resources.

23. Young, A. \& Fry, J.D. (2008) Metacognitive awareness and academic achievement in college students. Journal of the scholarship of teaching and learning, 4 (2): 18-26. 